\title{
Мультимодальні стратегії удосконалення інфекційної безпеки в закладах охорони здоров'я стоматологічного профілю
}

\author{
А.Г. Круть, О.К. Толстанов, В.В. Горачук \\ Національний університет охорони здоров'я України імені П.Л. Шупика, Київ, Україна
}

\begin{abstract}
Анотація. Мета: дослідити стан організації інфекційної безпеки та запропонувати мультимодальні стратегії її удосконалення в закладах охорони здоров'я стоматологічного профілю. Об'єкт дослідження: системи інфекційної безпеки в закладах третинної медичної допомоги стоматологічного профілю. Предмет дослідження: організаційна структура, функції, засоби, заходи з інфекційної безпеки в досліджуваних закладах. Методи дослідження: системний підхід; порівняльний, логіко-структурний аналіз; описове моделювання; графічний. Результати. Встановлено, що системи інфекційної безпеки функціонують відповідно до нормативних вимог. Однак програми профілактики інфекцій та інфекційного контролю не містять заходів з вакцинопрофілактики медичних працівників від парентеральних гепатитів та грипу, зі зміцнення культури інфекційної безпеки, відсутні чіткі критерії моніторингу й оцінки профілактичних заходів. Відсутні інструменти самоконтролю; обмежено використовується внутрішній аудит; не налагоджена чітка взаємодія між усіма зацікавленими сторонами; компоненти інфраструктури (інженерні мережі, комунікації) відокремлені від системи інфекційної безпеки. Використовуються традиційні методи навчання персоналу на робочих місцях. Запропоновані мультимодальні стратегії, спрямовані на використання світових доказових практик, запровадження чек-листів як носіїв критеріїв моніторингу й оцінки та інструменту самоконтролю, використання внутрішнього тематичного аудиту, налагодження комунікацій між зацікавленими сторонами, запровадження інтерактивних форм навчання працівників на робочих місцях та зміцнення культури інфекційної безпеки. Висновки. Використання комплексу мультимодальних стратегій, що базуються на світових доказових практиках, забезпечить удосконалення заходів з інфекційної безпеки в закладах охорони здоров'я стоматологічного профілю.
\end{abstract}

Ключові слова: профілактика інфекцій, інфекційний контроль, стоматологічна допомога, доказові практики, моніторинг, оцінка.

\section{Вступ}

Однією з глобальних проблем світових систем охорони здоров'я визнана інфекційна безпека, що засвідчено серією доповідей генерального директора Всесвітньої організації охорони здоров'я (ВОО3) [1-3]. Аналіз змін, що відбуваються в сфері охорони здоров'я за останні десятиріччя, показав поглиблення проблеми безпеки медичної допомоги за рахунок нових видів, технологій і моделей лікування як зворотного боку їх терапевтичної ефективності. Зокрема, в лікарнях країн з низьким і середнім рівнем економічного розвитку відмічають щороку 134 млн випадків несприятливих подій, пов'язаних з небезпечним наданням медичної допомоги, та 2,6 млн випадків смерті внаслідок цих подій, а в країнах з високим рівнем розвитку економіки шкода завдається приблизно кожному десятому пацієнту, який отримує лікарняну допомогу [4, 5].

У той самий час заходи із зменшення тягаря шкоди, завданої пацієнтам, поки що мають обмежений характер та нестійку ефективність. Основними загрозами для безпеки пацієнтів вважаються помилки, пов'язані із застосуванням лікарських засобів; інфекції, пов'язані з наданням медико-санітарної допомоги; небезпечні процедури при наданні хірургічної допомоги; небезпеки, пов'язані з ін'єкціями лікарських препаратів; діагностичні помилки; небезпечна практика переливання крові; помилки при використанні іонізуючого випромінювання; сепсис; венозна тромбоемболія; небезпечне надання допомоги в психіатричних закладах та ін.

Питання безпеки пацієнтів значно поглибилися під час поточної пандемії, викликаної коронавірусною інфекцією (COVID-19), зокрема інфекційної безпеки для пацієнтів та медичних працівників, у тому числі в закладах, де надається стоматологічна допомога.

Мета: дослідити стан організації інфекційної безпеки та запропонувати мультимодальні стратегії ії удосконалення в закладах охорони здоров'я стоматологічного профілю.

\section{0б'єкт і методи дослідження}

Об'єктами дослідження слугували системи інфекційної безпеки закладів третинної медичної допомоги стоматологічного профілю.
Предмет дослідження: організаційні структури та функції, засоби і заходи з інфекційної безпеки, які використовуються керівниками закладів.

Базами дослідження обрані комунальне некомерційне підприємство (КНП) «Житомирське обласне стоматологічне медичне об'єднання», КНП Харківської обласної ради «Обласна стоматологічна поліклініка», КНП «Чернігівська обласна стоматологічна поліклініка Чернігівської обласної ради» - заклади охорони здоров'я, що надають висококваліфіковану високоспеціалізовану стоматологічну допомогу населенню відповідних регіонів.

Використані методи системного підходу, порівняльного і логіко-структурного аналізу, описового моделювання, графічний.

Аналізували локальні документи (плани роботи, плани і графіки навчання персоналу, положення про структурні підрозділи та позаштатні структури, посадові інструкції працівників, накази, протоколи, методики, інструкції і т.і.), де представлені фактичні дані із забезпечення інфекційної безпеки в досліджуваних закладах (усього 97 одиниць).

Дослідження проводили в період 2019-2020 рр.

\section{Результати}

При аналізі матеріалів дослідження встановлено, що в кожному з досліджуваних закладів розроблені оперативно-тактичні плани діяльності, де окремий розділ містить заходи з інфекційної безпеки. Аналогічні заходи внесені до планів діяльності структурних підрозділів (амбулаторних та стаціонарних), затверджених керівниками закладів, з урахуванням обсягу і змісту делегованих повноважень на відповідний рівень управління. Відповідальність за виконання планових заходів з інфекційної безпеки покладена наказами керівників та посадовими інструкціями на медичного директора, завідувачів структурних підрозділів, головну та старших медичних сестер відділень/кабінетів.

Окремим положенням, затвердженим керівником кожного закладу, створено комісію з інфекційного контролю (КІК), на яку покладено функції з розробки Програми профілактики інфекцій та інфекційного контролю (ППІІК), а також моніторингу і контролю за виконанням програми. 
Складовими ППІІК $\epsilon$ заходи з гігієнічної та хірургічної обробки рук персоналу; профілактики післяопераційних гнійно-запальних інфекцій; дезінфекції, передстерилізаційної обробки, стерилізації інструментів та медичних виробів; генеральних і поточних прибирань приміщень; дезінфекції та прання білизни; щоденних медичних оглядів працівників; закупівлі і використання одноразового інструментарію, засобів для дезінфекції, стерилізації, дезінсекції, засобів індивідуального захисту; забезпечення готовності закладу до протиепідемічних дій на випадок занесення особливо небезпечних інфекцій; утилізації відходів.

До складу КІК входять завідувачі відділень, головні і старші медичні сестри; очолює КІК у кожному закладі медичний директор. Формою роботи КІК $\epsilon$ засідання, на яких обговорюються питання інфекційної безпеки за результатами поточного контролю та готуються рекомендації для керівника з проблемних питань. Інструментами систематичного збору даних (моніторингу) слугують безпосередні спостереження та перевірки дотримання персоналом заходів з інфекційної безпеки представниками ради медичних сестер, старшими сестрами відділень, головною медичною сестрою, завідувачами відділень, а також дані обліку випадків, які свідчать про несприятливі події в сфері інфекційної безпеки.

Здійснюється моніторинг якості дезінфекції та стерилізації медичного інструментарію, перев'язувального матеріалу, епідемічно значущих об'єктів в приміщеннях з асептичним режимом роботи, роботи стерилізаторів і автоклавів, стану здоров'я медичних працівників за результатами щоденного контролю та обов'язкових періодичних профілактичних медичних оглядів, режиму використання ламп ультрафіолетового опромінення, дотримання техніки миття рук, протоколів медичної сестри з виконання ін'єкцій, правил утилізації відходів, облік миючих та дезінфікуючих засобів, контроль дезінфекції та чистоти білизни. Підлягають обліку випадки внутрішньолікарняних інфекцій та дані мікробіологічного моніторингу стану післяопераційної рани, які фіксуються лікарями стоматологами-хірургами стаціонарних відділень і хірургічних кабінетів, випадки контакту осіб з кров'ю та біологічними матеріалами людини при виконанні професійних обов'язків.

До процесів «зворотного зв'язку» належить, крім моніторингу, розгляд питань дотримання санітарно-протиепідемічного режиму, випадків внутрішньолікарняних інфекцій та результатів інфекційного контролю на оперативних нарадах у керівників та на засіданнях медичних рад закладів, що засвідчено відповідними протоколами.

У кожному закладі відбувається за планом навчання персоналу з питань інфекційної безпеки як на робочих місцях (у відділеннях; на рівні закладу із спільних питань для працівників структурних підрозділів; під час засідань ради медичних сестер), так і в рамках безперервної медичної освіти поза межами закладів (на тематичних наукових конференціях, циклах тематичного удосконалення в закладах післядипломної освіти).

\section{Обговорення}

Логіко-структурний аналіз матеріалів дослідження та порівняльний аналіз їх контенту з нормативними вимогами засвідчив, що питання інфекційної безпеки в досліджуваних закладах вирішуються відповідно до регламентів для вітчизняних закладів охорони здоров'я [6-12].

Це обумовлює подібний характер та схожість прийнятих управлінських рішень і сформованих організаційних структур (адміністративно-ієрархічного типу та позаштатних), що займаються дотриманням, спостереженням та контролем за станом інфекційної безпеки у досліджуваних закладах. Ретельне слідування нормативним вимогам відповідає, зокрема, стандартам акредитації закладів охорони здоров'я, що засвідчено акредитаційними сертифікатами досліджуваних закладів з присвоєнням їм вищої акредитаційної категорії.

У той самий час відомо, що вища акредитаційна категорія закладам охорони здоров'я третинної медичної допомоги присво- юється в разі наявності в них сертифікованої системи управління якістю на відповідність ДСТУ ISO 9001:2015 «Системи управління якістю. Вимоги»; це також виявлено в досліджуваних закладах. Важливою вимогою до сертифікованих систем управління якістю $\epsilon$ їх спрямованість не лише на відповідність стандартам та/ або нормативним вимогам, але й на постійне поліпшення якості, і цей підхід стосується усіх видів діяльності, їі результатів та системи управління якістю, невід'ємною складовою якої в закладах охорони здоров'я $\epsilon$ інфекційна безпека.

Можливості розвитку й постійного удосконалення адміністративних підходів до управління інфекційною безпекою містяться у світовому досвіді із запровадження нових організаційних технологій в сфері інфекційної безпеки, зокрема, відповідних рекомендаціях ВОО3 [13-16] і специфічних для закладів охорони здоров'я стоматологічного профілю настановах щодо запобігання інфекціям і моніторингу діяльності з інфекційного контролю в межах профілактики інфекцій та інфекційного контролю, розроблених Центрами контролю та профілактики захворювань США $[17,18]$.

Зазначені матеріали створені на основі світових доказових практик з інфекційної безпеки та містять оновлену актуальну інформацію. Для закладів стоматологічного профілю такими доказовими практиками $\epsilon$ наступні: дотримання гігієни рук; використання засобів індивідуального захисту; стримування дихальних виділень у людей, які мають ознаки та симптоми респіраторної інфекції; безпека поводження з гострими предметами; практика безпечних ін'єкцій; стерилізація та дезінфекція предметів та пристроїв для догляду за пацієнтами; використання стерильної води в якості охолоджувальної рідини/зрошувача при виконанні хірургічних процедур (біопсії, пародонтальної хірургії, імплантації та хірургічного видалення зубів); очищення та дезінфекція клінічних контактних поверхонь; гігієна навколишнього середовища (прибирання приміщень, утилізація відходів). На основі цих доказових практик рекомендується розробляти локальні стандартні операційні процедури (СОП), адаптовані для закладів охорони здоров'я з метою чіткого розуміння й виконання доказових практик на даному робочому місці. В інструкціях та методиках, що використовують в досліджуваних закладах, виявлено відсутність конкретних дій для виконавців, оскільки в них дублюються матеріали з нормативних документів, які мають узагальнений характер.

Розробка і впровадження СОП передбачає функціонування системи моніторингу й оцінки їх виконання за відповідними критеріями. 3 метою ретельної оцінки виконання СОП застосовуються, за стандартами доказової практики, чек-листи, які водночас містять критерії правильного виконання технологій та слугують нагадуванням медичним працівникам щодо переліку, послідовності і правильності виконання процедур. У світовій практиці існують чек-листи з безпечної хірургічної практики, гігієни рук та профілактики інфекцій в стоматологічній практиці [17-19]. Їх доцільно адаптувати для закладів стоматологічного профілю, а також використати як зразок для розробки чек-листів при виконанні інших процедур з урахуванням місцевих умов. Для розробки чек-листів доцільно створювати робочі групи з працівників, які в подальшому використовуватимуть їх у своїй роботі як в якості регламентів, так і в якості інструментів нагадування/ контролю/самоконтролю.

У досліджуваних закладах функції моніторингу й оцінки ППІІК здійснюються лінійними керівниками (медичний директор, завідувачі відділень, головна медична сестра, старші медичні сестри відділень). В окремих випадках до моніторингу долучаються представники ради медичних сестер. Разом з тим такий інструмент управлінського контролю, як внутрішній аудит, передбачений ДСТУ ISO 9001:2015 «Системи управління якістю. Вимоги», для отримання більш об'єктивної оцінки діяльності на робочих місцях стосовно інфекційної безпеки використовується обмежено. Як засвідчено матеріалами дослідження, в межах одного внутрішнього аудиту здійснюється оцінка відповідності одночасно за кількома темами (правильність ведення медичної документації, дотримання клінічних протоколів, дотримання етико-деонтологічних норм, дотримання вимог санітарно-протиепідемічного режиму), що свідчить про поверхневу оцінку та формальний характер таких 
аудитів за наявності сертифіката відповідності системи управління якістю національному стандарту.

Незважаючи на багатоаспектність ППІІК, констатовано відокремленість від компонентів системи інфекційної безпеки таких складових інфраструктури, як будівлі, споруди та пов'язані 3 ними інженерні мережі (електро-, водопостачання і водовідведення, енерго- і теплозабезпечення, вентиляція, каналізація). Ці складові піддаються автономному управлінню, як зазначено в оперативно-тактичних планах роботи закладів, та їх належне функціонування і модернізація не входять до ППІІК. Як наслідок, до складу КІК не входять представники господарської служби, відповідальні за стан, належне функціонування та оновлення зазначених компонентів інфраструктури, не налагоджена чітка взаємодія з поточних і стратегічних питань інфекційної безпеки між членами KIK і радами медичних сестер, з одного боку, та представниками господарчої служби - 3 іншого. До складу медичних рад досліджуваних закладів представники господарчої служби також не входять; на засідання, де розглядаються питання інфекційної безпеки, не запрошуються. Така ситуація свідчить про приховані ризики епідемічної небезпеки для закладів внаслідок недооцінки ролі зазначених компонентів інфраструктури в профілактиці інфекцій та обмеженості комунікацій між відповідальними особами клінічних та господарчих служб.

Важливою складовою інфекційної безпеки слід вважати вакцинопрофілактику захворюваності на парентеральні гепатити, грип у медичних працівників, які безпосередньо надають стоматологічну допомогу. Така практика не набула в досліджуваних закладах постійного характеру.

Навчання медичних працівників та іншого персоналу безпосередньо на робочих місцях з питань інфекційної безпеки у досліджуваних закладах відбувається шляхом використання традиційних форм навчання з передачею знань усним або письмовим способом, візуалізацією матеріалів безпосередньо під час занять в аудиторії або дистанційно. Можливим підходом до підвищення ефективності навчання слід вважати впровадження інтерактивних форм навчальних занять в місці догляду за хворим або в інших місцях проведення процедур, передбачених заходами інфекційної безпеки, з демонстрацією викладачем правильності їх виконання у визначеній послідовності. Елементи навчання можна включати й до процедури внутрішнього аудиту, коли з метою оцінки відповідності аудитори використовують не лише підтверджувальні документи, але й на їх прохання персонал демонструє техніку проведення процедури, наприклад, гігієнічну обробку рук або поводження з гострими предметами. Доцільно використовувати щороку інструмент із самооцінки гігієни рук, запропонований ВОО3 [20], з метою оновлення знань персона- лу стосовно цієї важливої процедури. Як складова навчальних технологій можуть бути запроваджені регулярні тематичні мініконференції або «круглі столи» з представниками усіх служб, дотичних до питань інфекційної безпеки в закладі, що сприятиме як оновленню знань, так і поліпшенню комунікації.

Невід'ємною складовою інфекційної безпеки $\epsilon$ зміцнення клімату безпеки, тобто запровадження корпоративної культури, що базується не на пошуку винних, а на зборі даних з метою поліпшення діяльності та відповідної зміни поведінки працівників. Враховуючи, що в досліджуваних закладах документально не зареєстровано упродовж року порушень інфекційної безпеки, можна вважати доречним завданням формування такої корпоративної культури.

Запропоновані підходи в комплексі можна визначити як мультимодальні стратегії з підвищення рівня інфекційної безпеки в закладах стоматологічного профілю (таблиця).

Використання комплексу мультимодальних стратегій підвищить надійність заходів з профілактики реалізації прихованих ризиків інфекційної безпеки.

\section{Висновки}

Інфекційна безпека займає одне з пріоритетних місць в діяльності керівників закладів охорони здоров'я, що надають третинну медичну допомогу стоматологічного профілю.

Разом з тим сертифікація систем управління якістю медичної допомоги зобов'язує вище керівництво проводити постійний пошук нових організаційних технологій для удосконалення діяльності, їі результатів та самої системи.

Резерви удосконалення полягають у використанні світових доказових практик з інфекційної безпеки, зокрема розробці СОП для даного закладу охорони здоров'я з урахуванням специфіки та унікальності його діяльності; використанні чек-листів для оцінки відповідності дотримання процедур та нагадування персоналу про правильність їх виконання; поліпшенні комунікації відповідальних за інфекційну безпеку осіб; врахуванні усіх компонентів інфраструктури, які впливають на інфекційну безпеку, в ППІІК; використанні інструменту внутрішнього аудиту для об'єктивної оцінки відповідності діяльності з інфекційної безпеки; впровадженні інтерактивних методик навчання персоналу.

\section{Перспективи подальших досліджень}

Перспективи подальших досліджень полягають в оцінці результатів діяльності з інфекційної безпеки після впровадження запропонованих мультимодальних стратегій.

\section{Конфлікт інтересів}

Автори заявляють про відсутність конфлікту інтересів.

Таблиця Мультимодальні стратегії удосконалення інфекційної безпеки для закладів охорони здоров'я стоматологічного профілю

\begin{tabular}{|c|c|c|}
\hline $\begin{array}{l}\text { Назва елементу системи інфекційної } \\
\text { безпеки }\end{array}$ & Стратегії, що використовуються & Стратегії удосконалення \\
\hline $\begin{array}{l}\text { Нормативне регулювання інфекційної } \\
\text { безпеки }\end{array}$ & Дотримання галузевих нормативних вимог & $\begin{array}{l}\text { Додаткове використання світових доказових практик з інфекційної безпеки, } \\
\text { адаптованих для даного закладу охорони здоров'я }\end{array}$ \\
\hline \multirow[t]{2}{*}{ Моніторинг і оцінка заходів ППІІК } & $\begin{array}{l}\text { Нечіткість критеріїв моніторингу й оцінки, відсутність } \\
\text { інструментів самоконтролю }\end{array}$ & $\begin{array}{l}\text { Запровадження чек-листів як носіїв критеріїв моніторингу, оцінки та інструменту } \\
\text { самоконтролю (нагадувань) }\end{array}$ \\
\hline & $\begin{array}{l}\text { Наділення повноваженнями з моніторингу й оцінки } \\
\text { лінійних керівників }\end{array}$ & $\begin{array}{l}\text { Використання внутрішнього тематичного аудиту для оцінки відповідності заходів } \\
\text { інфекційної безпеки ППІІК }\end{array}$ \\
\hline $\begin{array}{l}\text { Компоненти інфраструктури (інженерні } \\
\text { мережі, комунікації) }\end{array}$ & Відокремлення від системи інфекційної безпеки & $\begin{array}{l}\text { Включення до ППІІК заходів з підтримки функціонування й модернізації } \\
\text { компонентів інфраструктури (інженерних мереж, комунікацій) }\end{array}$ \\
\hline KIK & Формування складу з медичних працівників & Введення до складу KIК представників інженерно-господарчої служби \\
\hline Комунікація з питань інфекційної безпеки & $\begin{array}{l}\text { Практикуються між клінічними відділеннями; між } \\
\text { клінічними відділеннями й адміністрацією; між } \\
\text { клінічними відділеннями, адміністрацією і позаштатними } \\
\text { структурами (КІК, медична рада, рада медичних сестер) }\end{array}$ & $\begin{array}{l}\text { Налагодження комунікації між зацікавленими сторонами в інфекційній безпеці: } \\
\text { клінічними відділеннями, адміністрацією, пацієнтами, їх представниками, } \\
\text { позаштатними структурами (КІК, медична рада, рада медичних сестер, внутрішній } \\
\text { аудит), інженерно-господарчою службою, вищими органами управління }\end{array}$ \\
\hline $\begin{array}{l}\text { Вакцинопрофілактика парентеральних } \\
\text { гепатитів, грипу у медичних працівників }\end{array}$ & Не застосовується в межах ППІІК & Включення до заходів ППІІК \\
\hline $\begin{array}{l}\text { Навчання працівників } 3 \text { питань } \\
\text { інфекційної безпеки }\end{array}$ & $\begin{array}{l}\text { Використання традиційних форм навчання на робочих } \\
\text { місцях }\end{array}$ & Запровадження інтерактивних форм навчання на робочих місцях \\
\hline Корпоративна культура & Не застосовується в межах ППІІК & $\begin{array}{l}\text { Зміцнення культури інфекційної безпеки, що базується не на пошуку винних, а на зборі } \\
\text { даних з метою поліпшення діяльності та відповідної зміни поведінки працівників }\end{array}$ \\
\hline
\end{tabular}




\section{Список використаної літератури/References:}

1. World Health Organization (2018) Patient safety. Global action to ensure patient safety. Report of the General Director (apps.who.int/gb/ebwha/pdf_files/EB144/B144_29-ru.pdf). (In Rus.).

2. World Health Organization (2019) Patient safety. Global action to ensure patient safety. Report of the General Director (apps.who.int/gb/ebwha/pdf_files/WHA72/A72_27-ru.pdf).

3. World Health Organization (2021) Patient safety. Global action to ensure patient safety. Report of the General Director (apps.who.int/gb/ebwha/pdf_files/EB148/B148_6-ru.pdf).

4. Slawomirski L., Auraaen A., Klazinga N.S. et al. (2017) The Economics of Patient Safety:Strengthening a value-based approach to reducing patient harm at national level (www.oecd-library.org/ docserver $/ 5$ a9858cd-en.pdf?expires=1593688230\&id=id\&accname=guest\&checksum=B1730 733897FC2DC01D171(38D4218F2).

5. National Academies of Sciences, Engineering, and Medicine (2018) Crossing the Global Quality Chasm: Improving Health Care Worldwide (doi.org/10.17226/25152).

6. State Committee of Ukraine on Industrial Safety, Labour Protection and Mountain Supervision (2007) Order of the StateCommittee of Ukraine on Industrial Safety, Labour Protection and Mountain Supervision from 28.12.2007 № 331 «About the statement of Rules of a choice and application of means of individual protection of respiratory organs») (zakon.rada.gov.ua/laws/show/Z028508\#Text) (In Ukr.).

7. Ministry of Health of Ukraine (2010) Order of the Ministry of Health of Ukraine from 21.09.2010 № 798 «About the statement of methodical recommendations «Surgical and hygienic processing of hands of medical staffy (zakon.rada.gov.ua/rada/show/v0798282-10\#Text) (In Ukr.).

8. Ministry of Health of Ukraine (2013) Order of the Ministry of Health of Ukraine from 01.06.2013 № 460 «About the statement of protocols of the nurse (paramedic, midwife) on care of the patient and performance of the basic medical procedures and manipulations») (zakon.rada.gov.ua/rada/ show/v0460282-13\#Text) (In Ukr.)

9. Ministry of Health of Ukraine (2014) Order of the Ministry of Health of Ukraine from 11.08.2014 № 552 «On approval of the State sanitary norms and rules «Disinfection, pre-sterilization cleaning and sterilization of medical devices in health care facilities» (zakon.rada.gov.ua/laws/show/z106714\#Text) (In Ukr.).

10. Ministry of Health of Ukraine (2014) Order of the Ministry of Health of Ukraine from 30.04.2014 № 293 «About approval of the Instruction on collection, sorting, transportation, storage, disinfection and washing of linen in health care facilities» (zakon.rada.gov.ua/laws/show/z0556-14\#Text) (In Ukr.).

11. Ministry of Health of Ukraine (2015) Order of the Ministry of Health of Ukraine from 08.06.2015 № 325 «About the statement of the State sanitary and anti-epidemic rules and norms concerning management of medical waste» (zakon.rada.gov.ua/laws/show/Z0959-15\#Text) (In Ukr.).

12. Ministry of Social Policy of Ukraine (2018) Order of the Ministry of Social Policy of Ukraine from 29.11.2018 № 1804 «About the statement of the Minimum requirements of safety and health protection at use by workers of personal protective equipment at a workplaces) (zakon.rada.gov. ua/laws/show/z1494-18\#Text) (In Ukr.).

13. World Health Organization (2016) Global Guidelines for the Prevention of Surgical Site Infection. Geneva, 186p.

14. World Health Organization (2016) Guidelines on core components of infection prevention and control programmes at the national and acute health care facility level. Geneva, $91 \mathrm{p}$.

15. World Health Organization (2018) Implementation manual to support the prevention of surgical site infections at the facility level — turning recommendations into practice. Geneva, $136 \mathrm{p}$.

16. World Health Organization (2019) Minimum requirements for infection prevention and control. Geneva, $70 \mathrm{p}$.
17. Centers for Disease Control and Prevention (2016) Infection Prevention Checklistfor Dental Settings: Basic Expectations for Safe Care. Atlanta, 20 p. (www.cdc.gov/oralhealth/infectioncontrol/pdf/ safe-care-checklist.pdf).

18. Centers for Disease Control and Prevention (2016). Summary of Infection Prevention Practices in Dental Settings: Basic Expectations for Safe Care. Atlanta, $44 \mathrm{p}$.

19. World Health Organization (2009) Implementation manual WHO surgical safety checklist 2009: safe surgery saves lives. Geneva, Switzerland, $20 \mathrm{p}$.

20. World Health Organization (2010) Hand Hygiene Self-Assessment Framework 2010. Introduction and user instructions (www.who.int/gpsc/country_work/hhsa_framework_0ctober_2010. pdf?ua=1).

\section{Multimodal strategies to improve infectious safety in dental health care facilities}

\section{A.G. Krut, O.K. Tolstanov, V.V. Horachuk}

Shupyk National Healthcare University of Ukraine, Kyiv, Ukraine

Abstract. Purpose: to study the state of the organization of infectious safety and to offer multimodal strategies for its improvement in dental healthcare facilities. The object of research: infectious safety systems in tertiary care facilities of dental profile. The subject of research: the organizational structure, functions, tools, measures for infectious safety in the studied institutions. Research methods: system approach; comparative, logical and structural analysis; descriptive modeling; graphic. Results. It is established that infectious safety systems operate in accordance with regulatory requirements. However, infection prevention and control programs do not include measures to vaccinate health workers against parenteral hepatitis and influenza and to strengthen the culture of infectious safety, there are no clear criteria for monitoring and evaluating preventive measures. There are no tools for self-control on infectious safety issues, internal audit is used to a limited extent; clear interaction between all stakeholders is not established; infrastructure components (engineering networks, communications) are separated from the infectious safety system. Traditional methods of staff training are used in the workplace. Multimodal strategies based on world evidence-based practices on infectious safety have been proposed to be used to improve the organization of infectious safety activities. It is recommended to introduce checklists as carriers of criteria for monitoring, evaluation and self-control tools, use of internal thematic audit, establishment of communications between stakeholders, introduction of interactive forms of employee training in the workplace and strengthening the culture of infectious safety. Conclusions. The use of a set of multimodal strategies based on world evidence-based practices will ensure the improvement of infectious safety measures in dental healthcare facilities.

Key words: infection prevention, infection control, dental care, evidence-based practices, monitoring, evaluation.

\begin{abstract}
Відомості про авторів:
Круть Анатолій Григорович — кандидат медичних наук, доцент, директор Стоматологічного навчально-практичного медичного центру Національного університету охорони здоров'я України імені П.Л. Шупика, Київ, Україна. ORCID ID: 0000-0001-6503-3952

Толстанов Олександр Костянтинович — доктор медичних наук, професор, проректор з науково-педагогічної роботи, професор кафедри управління та публічного адміністрування Національного університету охорони здоров'я України імені П.Л. Шупика, Київ, Україна. ORCID ID: 0000-0002-7459-8629 Горачук Вікторія Валентинівна — доктор медичних наук, професор кафедри управління та публічного адміністрування, учений секретар Національного університету охорони здоров'я України імені П.Л. Шупика, Київ, Україна. ORCID ID: 0000-0002-6076-8711
\end{abstract}

\section{Адреса для кореспонденції:}

Горачук Вікторія Валентинівна

04112, Київ, вул. Дорогожицька, 9

E-mail: gorachuk@ukr.net

\section{Information about the authors:}

Krut Anatoliy G. - Candidate of Medical Sciences, Associate Professor, Director of the Dental Educational and Practical Medical Center of the Shupyk National Healthcare University of Ukraine, Kyiv, Ukraine. ORCID ID: 0000-0001-6503-3952

Tolstanov Olexandr K. - Doctor of Medical Sciences, Professor, Vice-rector for scientific and pedagogical work, Professor of the Department of management and public administration of the Shupyk National Healthcare University of Ukraine, Kyiv, Ukraine. ORCID ID: 0000-0002-7459-8629 Gorachuk Victoria V. — Doctor of Medical Sciences, Professor of the Department of management and public administration, Scientific secretary of the Shupyk National Healthcare University of Ukraine, Kyiv, Ukraine. ORCID ID: 0000-0002-6076-8711

\section{Address for correspondence:}

Victoria Gorachuk

04112, Kyiv, Dorohozhytska str., 9

E-mail: gorachuk@ukr.net 